\title{
PENGARUH TERAPI PSIKORELIGIUS TERHADAP KECEMASAN LANSIA PADA MASA PANDEMI COVID 19 DI UPT PESANGGRAHAN PMKS MOJOPAHIT MOJOKERTO
}

\author{
Mujiadi \\ Program Studi s1 Ilmu Keperawatan STIKES Majapahit Mojokerto
}

\begin{abstract}
The problem of the COVID-19 pandemic is still a threat to society, especially the elderly. The negative impact they experience is not only in the form of physical illness in the form of signs and symptoms of fever, cough, anorexia, shortness of breath and other respiratory system disorders that cause death, they also experience mental stress in the form of fear of contracting the disease. The research design that will be used in this study is a pre-experimental one group pretest-posttest design. The population in this study were all the elderly who inhabit PMKS Mojopahit and the sample was the elderly who met the inclusion criteria with simple random sampling technique and the sample size was 30 respondents. Of the 13 elderly who experienced severe anxiety before being given psychoreligious therapy as many as 10 people (33.4\%) experienced moderate anxiety after being given psychoreligious therapy and a small proportion of 3 people (10\%) still experienced severe anxiety. Of the 14 elderly who experienced moderate anxiety before psychoreligious therapy, 6 people (20\%) experienced mild anxiety, 7 people (23.3\%) experienced moderate anxiety and 1 person (3.3\%) experienced severe anxiety. Of the 3 elderly who experienced mild anxiety before taking psychoreligious therapy, it was found that 2 people $(6.7 \%)$ experienced mild anxiety after being given psychoreligious therapy and 1 person (3.3\%) experienced moderate anxiety. So to control it is necessary to change personal perceptions about a situation to overcome the situation, namely attitudes, beliefs and thoughts must be positive and control other causal factors so that anxiety is reduced or can be transferred.
\end{abstract}

Keywords: elderly, anxiety, psychoreligious

\section{A. PENDAHULUAN}

Unit Peyanan Terpadu (UPT) Penyandang Masalah Kesejahteraan Sosial (PMKS) merupakan tempat singgah dan perawatan bagi lanjut usia yang mempunyai masalah keterbatasan dalam pemenuhan kebutuhan hidupnya. Semua pengelolaan yang berada di PMKS tersebut dibawah pengawasan Dinas Sosial di kabupaten Mojokerto. Sebagian besar lansia yang menghuni di PMKS tidak mempunyai anggota keluarga dan sebagian kecil yang masih mempunyai anggota keluarganya. Seiring dengan bertambahnya usia maka semakin menurun pula fisik dan mental lansia. Banyak penyakit degenerative yang mereka alami sehingga menurunkan aktivitas fisik maupun psikologisnya. Kondisi inilah yang menjadi ancaman atau risiko munculnya bahaya pada lansia karena penurunan daya tahan tubuh akan memudahkan penyakit masuk kedalam tubuhnya, baik penyakit fisik maupun penyakit psikologisnya. Masalah pandemic covid 19 masih menjadi ancaman bagi masyarakat terutama golongan lanjut usia. Dampak negative yang mereka alami tidak hanya berupa sakit fisik saja yang berupa tanda dan gejala demam, batuk, anoreksia, sesak dan gangguan system pernafasan yang lainnya yang menyebabkan kematian, mereka juga mengalami tekanan mental berupa kekawatiran akan tertular penyakit tersebut. 
Prevalensi kasus covid 19 didunia hingga Oktober 2020 mencapai 41,1 juta kasus positif covid 19. Kasus covid 19 di Indonesia pada bulan yang sama mencapai 368.842 kasus positif terpapar dengan rincian meninggal dunia sebanyak 12.734 jiwa. Kasus positif terpapar virus covid 19 di kabupaten Mojokerto sebanyak 971 kasus dan yang meninggal sebanyak 31 orang (Kemenkes RI, 2020). Sedangkan pada bulan Februari 2021sebanyak sekitar 15.023 lansia meninggal dunia karena Covid-19 dari total 31.763 pasien meninggal di Indonesia hingga 47,3\% kasus positif Covid-19 meninggal kelompok umur lebih dari 60 tahun (covid19.go.id).

Banyaknya angka kasus terpapar maupun meningkatnya jumlah penderita yang meninggal akan membuat masyarakat menjadi kawatir akan terpapar covid 19 dan menimbulkan kecemasan. Kondisi ini juga dialami oleh lansia yang berada di PMKS Mojopahit Mojokerto. Kecemasan ini dapat menurunkan imunitas tubuh dan tentunya dapat menyebabkan seseorang lansia rentan terhadap infeksi termasuk COVID-19. Hal itu terjadi karena lanjut usia sering dikaitkan dengan kelompok yang rentan terhadap berbagai penyakit oleh karena fungsi fisiologisnya. Berangsur-angsur berkurang antara lain sistem imun tubuh.

Masa diberlakukannya pembatasan social dan pembatasan jarak fisik (Social distancing/physical distancing) akibat pandemic COVID-19 ini tentunya menimbulkan ketidaknyamanan bagi semua orang termasuk lansia, kurangnya melakukan aktivitas fisik diluar PMKS membuat lansia merasa bosan, agar tidak merasa cemas, dapat dialihkan dengan melakukan aktivitas yang menenangkan batin dan pikiran didalam PMKS misalnya dengan aktivitas yang bersifat spiritual. Aktivitas tersebut dapat berupa doa bersama, ceramah agama serta bacaan surat Yasin. Tujuan dari kegiatan tersebut adalah lansia tetap tenang tidak kawatir dan takut dengan situasi pandemic covid 19 sehingga akan memberikan efek ketenangan dalam batin dan pikirannya. Masyarakat Indonesia yang religius memandang Covid-19 sebagai ujian yang harus dilalui. Berpikir positif dengan selalu menjaga imunitas tubuh dan spiritualitas menjadi salah satu cara agar terhindar dari kecemasan. Memanfaatkan waktu yang sebaik-baiknya untuk beraktivitas secara positif dengan tetap memperhatikan protokol kesehatan menjadi solusi dalam menghadapi cemas di masa pandemi Covid-19.

\section{B. TINJAUAN PUSTAKA}

\section{Konsep Lansia}

\section{Batasan usia}

a. Usia lanjut presenilis yaitu antara usia 45-59 tahun,

b. Usia lanjut yaitu usia 60 tahun ke atas,

c. Usia lanjut beresiko yaitu usia 70 tahun ke atas atau usia 60 tahun ke atas dengan masalah kesehatan.

\section{Ciri-ciri lansia}

\section{Lansia merupakan periode kemunduran.}

Kemunduran pada lansia sebagian datang dari faktor fisik dan faktor psikologis.

Motivasi memiliki peran yang penting dalam kemunduran pada lansia. Misalnya lansia yang memiliki motivasi yang rendah dalam melakukan kegiatan, maka akan mempercepat proses kemunduran fisik, akan tetapi ada juga lansia yang memiliki 
motivasi yang tinggi, maka kemunduran fisik pada lansia akan lebih lama terjadi.

\section{Masalah yang dialami lansia}

a. Masalahyang hadapi oleh lansia adalah fisik yang mulai melemah, sering terjadi radang persendian ketika melakukan aktivitas yang cukup berat, indra pengelihatan yang mulai kabur, indra pendengaran yang mulai berkurang serta daya tahan tubuh yang menurun, sehingga sering sakit.

b. Masalah yang hadapi lansia terkait dengan perkembangan kognitif, adalah melemahnya daya ingat terhadap sesuatu hal (pikun), dan sulit untuk bersosialisasi dengan masyarakat di sekitar.

c. Masalah yang hadapi terkait dengan perkembangan emosional, adalah rasa ingin berkumpul dengan keluarga sangat kuat, sehingga tingkat perhatian lansia kepada keluarga menjadi sangat besar. Selain itu, lansia sering marah apabila ada sesuatu yang kurang sesuai dengan kehendak pribadi dan sering stres akibat masalah ekonomi yang kurang terpenuhi

d. Masalah yang dihadapi terkait dengan perkembangan spiritual, adalah kesulitan untuk menghafal kitab suci karena daya ingat yang mulai menurun, merasa kurang tenang ketika mengetahui anggota keluarganya belum mengerjakan ibadah, dan Merasa gelisah ketika menemui permasalahan hidup yang cukup serius.

\section{Konsep Kecemasan}

\section{Definisi}

Kecemasan suatu perasaan takut yang bersifat lama pada sesuatu yang tidak jelas dan berhubungan dengan perasaan yang tidak menentu dan tidak berdaya. Seseorang akan mengahadapi situasi yang tidak pasti dan tidak menentu terhadap kemampuannya dalam menghadapi suatu masalah dan dampaknya berupa emosi yang kurang menyenangkan yang dialami oleh individu dan bukan kecemasan sebagai sifat yang melekat pada diri setiap individu. (Potter,2010)

\section{Aspek Kecemasan}

Kecemasan menjadi tiga aspek, yaitu:

a. Aspek fisik, seperti pusing, sakit kepala, tangan mengeluarkan keringat, menimbulkan rasa mual pada perut, mulut kering, grogi, dan lain-lain

b. Aspek emosional, seperti timbulnya rasa panik dan rasa takut

c. Aspek mental atau kognitif, timbulnya gangguan terhadap perhatian dan memori, rasa khawatir,ketidakteraturan dalam berpikir, dan bingung

\section{Konsep Psikoreligius}

\section{Definisi}

Psikoreligi merupakan suatu intervensi dalam praktek keperawatan yang menggunakan pendekatan keagamaan antara lain berdoa, dzikir ceramah keagamaan, dan lain-lain untuk meningkatkan kekebalan dan daya tahan dalam menghadapi berbagai problem kehidupan yang merupakan stressor psikososial guna peningkatan integrasi kesehatan jiwa (Teguh, 2020). 


\section{Bentuk kegiatan}

Terapi spiritual adalah terapi dengan memakai upaya-upaya untuk mendekatkan diri pada Tuhan. Ini sama dengan terapi keagamaan, religius, dan psikoreligius, yang berarti terapi dengan menggunakan faktor agama, kegiatan ritual keagamaan, seperti sembahyang, berdoa, dzikir, memanjatkan puji-pujian, ceramah agama, kajian kitab suci, dan sebagainya. Hanya saja terapi spiritual lebih umum sifatnya dan tidak selalu dengan agama formal masing-masing individu (Wicaksono, 2012)

Pengertian terapi spiritual dan terapi psikoreligius adalah sebuah terapi dengan pendekatan terhadap kepercayaan yang dianut oleh klien, pendekatan ini dilakukan oleh seseorang pemuka agama dengan cara memberikan pencerahan, kegiatan ini dilakukan minimal I kali seminggu untuk semua klien dan setiap hari untuk pasien terapi spiritual berbeda dengan berdoa, doa tersebut ditiupkan disebuah gelas berisi air minum kemudian meminta klien meminum air tersebut, meskipun sama - sama menggunakan sebuah perilaku dalam sebuah agama atau kepercayaan tetapi akan sangat beda dengan terapi spiritual (Rumadani, 2018).

\section{Konsep Covid 19}

\section{Karakteristik}

Coronavirus Disease 2019 (COVID-19) adalah penyakit jenis baru yang belum pernah diidentifikasi sebelumnya pada manusia, penyebab COVID-19 ini dinamakan Sars-CoV-2.

\section{Penularan}

Menurut WHO, 2020. Transmisi SARS-CoV-2 dari pasien simptomatik terjadi melalui droplet yang keluar saat batuk atau bersin. COVID-19 dapat menyebar dari orang ke orang melalui :

a. Tidak sengaja menghirup percikan ludah dari bersin atau batuk pengidap COVID-19

b. Menyentuh tangan atau wajah orang yang terinfeksi

c. Menyentuh mata, hidung,atau mulut, setelah memegang barang yang terkena percikan air liur pengidap COVID-19 Tinja atau feses (jarang terjadi)

d. Kontak jarak dekat dengan penderita COVID-19, misal bersentuhan atau berjabat tangan.

\section{Pencegahan}

Menurut (Kemendagri, 2020).Berdasarkan bukti yang tersedia, tindakan pencegahan dan mitigasi merupakan kunci penerapan di pelayanan kesehatan dan masyarakat. Langkah-langkah pencegahan yang paling efektif di masyarakat meliputi:

a. Melakukan kebersihan tangan menggunakan hand sanitizer jika tangan tidak terlihat kotor atau cuci tangan dengan sabun jika tangan terlihat kotor

b. Menghindari menyentuh mata, hidung dan mulut

c. Terapkan etika batuk atau bersin dengan menutup hidung dan mulut dengan lengan atas bagian dalam atau tisu, lalu buanglah tisu ke tempat sampah 
d. Pakailah masker medis jika memiliki gejala pernapasan dan melakukan kebersihan tangan setelah membuang masker

e. Menjaga jarak (minimal $1 \mathrm{~m}$ ) dari orang yang mengalami gejala gangguan pernapasan..

\section{METODE PENELITIAN}

Desain penelitian yang akan digunakan dalam penelitian ini adalah pra ekperimental one group pretest-posttest design, yaitu dengan mengobservasi suatu kelompok kemudian memberikan perlakuan, dan hasilnya diobservasi agar diketahui keakuratan perlakuan (Sugiyono, 2018). Populasi dalam penelitian ini adalah seluruh lansia yang menghuni PMKS Mojopahit dan sampelnya adalah lansia yang memenuhi kriteria inklusi dengan tehnik simple random sampling dan didapatkan jumlah sampelnya 30 responden.

\section{HASIL PENELITIAN}

\section{Data Umum}

\section{a. Distribusi Frekuensi Berdasarkan Usia Responden}

Table 1. Distribusi Frekuensi Berdasarkan Usia Responden di Pesanggrahan PMKS Mojopahit Mojokerto

\begin{tabular}{|c|c|c|c|}
\hline No & Usia & Frekuensi & Prosentase (\%) \\
\hline 1 & $<60$ Tahun & 10 & 33,3 \\
\cline { 2 - 4 } 2 & $61-70$ Tahun & 16 & 53,4 \\
\hline 3 & $>71$ Tahun & 4 & 13,3 \\
\hline \multicolumn{2}{|c|}{ Total } & 30 & 100,0 \\
\hline
\end{tabular}

Berdasarkan table diatas bahwa responden terbanyak pada lansia dengan rentang usia 61 - 70 tahun sebanyak 16 orang $(53,4 \%)$ dan paling sedikit lansia pada usia lebih dari 71 tahun sebanyak 4 orang $(13,3 \%)$.

\section{b. Distribusi Frekuensi Berdasarkan Jenis Kelamin Responden}

Table 2. Distribusi Frekuensi Berdasarkan Jenis Kelamin Responden di Pesanggrahan PMKS Mojopahit Mojokerto

\begin{tabular}{|c|c|c|c|}
\hline No & Jenis kelamin & Frekuensi & Prosentase (\%) \\
\hline 1 & Laki-laki & 20 & 66,7 \\
\hline 2 & Perempuan & 10 & 33,3 \\
\hline & Total & 30 & 100,0 \\
\hline
\end{tabular}

Berdasarkan table 2 diatas bahwa 30 responden lansia berjenis kelamin laki-laki sebanyak 20 orang $(66,7 \%)$ dan lansia berjenis kelamin perempuan 
sebanyak 10 orang $(33,3 \%)$.

c. Distribusi Frekuensi Berdasarkan Pendidikan Responden

Table 3. Distribusi Frekuensi Berdasarkan Pendidikan Responden di Pesanggrahan PMKS Mojopahit Mojokerto

\begin{tabular}{|c|c|c|c|}
\hline No & Pendidikan & Frekuensi & Prosentase (\%) \\
\hline 1 & Tidak Sekolah & 8 & 27 \\
\hline 2 & SD & 12 & 40 \\
\hline 3 & SMP & 6 & 20 \\
\hline 4 & SMA & 4 & 13 \\
\hline \multicolumn{2}{|r|}{ Total } & 30 & 100,0 \\
\hline
\end{tabular}

Berdasarkan table 3 diatas bahwa responden terbanyak pada lansia dengan tingkat pendidikan SD sebanyak 12 orang (40\%).

\section{Data Khusus}

\section{a. Kecemasan sebelum diberikan terapi psikoreligius}

Table 4 Kecemasan sebelum diberikan terapi psikoreligius di Pesanggrahan PMKS Mojopahit Mojokerto

\begin{tabular}{|c|c|c|c|}
\hline No & Tingkat Stress & Frekuensi & Prosentase (\%) \\
\hline 1 & Ringan & 3 & 10 \\
\hline 2 & Sedang & 11 & 37 \\
\hline 3 & Berat & 16 & 53 \\
\hline \multicolumn{2}{|r|}{ Total } & 30 & 100,0 \\
\hline
\end{tabular}

Berdasarkan table 4 diatas bahwa responden sebelum diberikan terapi psikoreligius didapatkan tingkat cemas ringan 3 orang (10\%), cemas sedang 11 orang $(37 \%)$ dan cemas berat sebanyak 16 Orang $(53 \%)$

\section{b. Kecemasan sesudah diberikan terapi psikoreligius}

Table 5 Kecemasan sesudah diberikan terapi psikoreligius di Pesanggrahan PMKS Mojopahit Mojokerto

\begin{tabular}{|c|c|c|c|}
\hline No & Tingkat Stress & Frekuensi & Prosentase (\%) \\
\hline 1 & Ringan & 8 & 27 \\
\hline 2 & Sedang & 18 & 60 \\
\hline 3 & Berat & 4 & 13 \\
\hline \multicolumn{2}{|r|}{ Total } & 30 & 100,0 \\
\hline
\end{tabular}


Berdasarkan table 5 diatas bahwa responden sesudah diberikan terapi psikoreligius didapatkan tingkat cemas ringan 8 orang (27\%), cemas sedang 18 orang $(60 \%)$ dan cemas berat sebanyak 4 Orang (13\%)

\section{c. Pengaruh Psikoreligius Terhadap Kecemasan}

Table 6 Pengaruh Terapi Psikoreligius Terhadap Kecemasan lansia di Pesanggrahan PMKS Mojopahit Mojokerto

\begin{tabular}{|c|c|c|c|c|c|c|c|c|c|}
\hline \multirow{2}{*}{ No } & \multirow{2}{*}{$\begin{array}{l}\text { Tingkat } \\
\text { cemas Pre }\end{array}$} & \multicolumn{6}{|c|}{ Tingkat cemas Post } & \multirow{2}{*}{ Total } & \multirow{2}{*}{$\%$} \\
\hline & & Ringan & $\%$ & Sedang & $\%$ & Berat & $\%$ & & \\
\hline 1 & Ringan & 2 & 6,7 & 1 & 3,3 & 0 & 0 & 3 & 100.0 \\
\hline 2 & Sedang & 6 & 20 & 7 & 23,3 & 1 & 3,3 & 14 & 100.0 \\
\hline 3 & Berat & 0 & 0 & 10 & 33,4 & 3 & 10 & 13 & 100.0 \\
\hline & Total & 8 & 26,7 & 18 & 60 & 4 & 13,3 & 30 & 100.0 \\
\hline \multicolumn{10}{|c|}{$\mathrm{Z}=-3,962$ dan $\mathrm{P}=0,000$} \\
\hline
\end{tabular}

Berdasarkan table 6 diatas bahwa dari 13 lansia yang mengalami cemas berat sebelum diberikan terapi psikoreligius sebanyak 10 orang $(33,4 \%)$ mengalami cemas sedang setelah diberikan terapi psikoreligius dan sebagian kecil 3 orang (10\%) masih mengalami cemas berat. Dari 14 lamsia yang mengalami cemas sedang sebelum dilakukan terapi psikoreligius didapatkan sebanyak 6 orang (20\%) mengalami cemas ringan, sebanyak 7 orang $(23,3 \%)$ mengalami cemas sedang dan 1 orang $(3,3 \%)$ mengalami cemas berat. Dari 3 lansia yang mengalami cemas ringan sebelum dilakukan tindakan terapi psikoreligius didapatkan 2 orang $(6,7 \%)$ mengalami cemas ringan sesudah diberikan terapi piskoreligius dan 1 orang $(3,3 \%)$ mengalami cemas sedang

\section{E. PEMBAHASAN}

\section{Kecemasan sebelum diberikan terapi psikoreligius}

Berdasarkan table 4 diatas bahwa responden sebelum diberikan terapi psikoreligius didapatkan tingkat cemas ringan 3 orang (10\%), cemas sedang 11 orang (37\%) dan cemas berat sebanyak 16 0rang (53\%). Lansia yang mengalami kecemasan berat secara emosi individu mengalami ketakutan akan terpapar covid 19 dan takut akan mati duluan di bandingkan teman-temannya dank arena rata-rata mereka usianya di bawah 60 tahun dengan paling banyak didominasi kaum perempuan hal ini dikarenakan perempuan lebih mengutamakan perasaannya sehingga ketika mengahadapi suatu masalah mereka lebih merasakan bersalah dan mudah merasakan cemas.terdapat satu orang lansia yang mengalami cemas berat meskipun usianya sudah diatas 71 tahun. Semakin tua usia seseorang maka akan semakin banyak pengalaman hidup sehingga ketiak mengahdapi suatu masalah maka akan semakin mudah dalam mengahadapi dan tidak mudah cemas. Kondisi yang dialami lansia ini berbeda karena sebelum masa pandemic covid 19, lansia sangat aktif bersosialisasi dengan warga sekitar pesanggrahan. Selama pandemic covid 19 dilakukan pembatasan fisik sehingga tidak 
boleh keluar dari pesanggrahan sehingga kondisi inilah lansia ini merasakan tekanan baginya.

\section{Kecemasan sesudah diberikan terapi psikoreligius}

Berdasarkan table 5 diatas bahwa responden sesudah diberikan terapi psikoreligius didapatkan tingkat cemas ringan 8 orang (27\%), cemas sedang 18 orang (60\%) dan cemas berat sebanyak 4 0rang (13\%).

Pengaruh terapi psikoreligius berdampak pada perubahan tingkat kecemasan lansia yang sebelumnya terdapat 16 lansia yang mengalami cemas berat dan setelah menjalani terapi psikoreligius menjadi 4 lansia yang masih mengalami cemas berat. Beberapa factor yang mempengaruhi adalah tingkat pendidikannya. Semua responden yang mengalami cemas berat dengan tingkat pendidikan tidak sekolah. Mereka kesulitan untuk merubah pola pikiran dan kemampuan untuk merubah sudut pandang bahwa hidup dan mati adalah takdir Allah SWT Tuhan semesta alam. Merka masih merasakan kawatir dan takut akan terpapar covid 19 dan akan cepat mati. Sedangkan mereka yang mampu menerima kondisi ini dan menjalankan terapi psikoreligius dengan baik masuk pada tingkatan cemas sedang dan ringan. Mereka yang mampu mengendalikan tingkat cemasnya ke level ringan adalah pada level usia diatas 61 tahun. Mereka yang di bawah usia 60 tahun merasa bahwa mereka masih mampu beraktivitas dan tidak mau mati dahulu. Kondisi inilah membuat mereka menjadi kawatir dan cemas.

Utami (2016) menyampaikan bahwa dzikir dan istighosah ditinjau dari aspek kesehatan memberikan dampak positif yang menyebabkan mekanisme keseimbangan tubuh tetap stabil. Ketidakseimbangan dalam diri seseorang mengakibatkan gangguan secara fisiologis. Sangat diperlukan adanya penanganan atau intervensi yang juga melibatkan aspek spiritual seseorang, seperti penelitian terdahulu mengatakan terapi dzikir dan do'a dengan pernapasan yang teratur dapat mempengaruhi kerja otak terutama pada cortek otak (Atik S dkk, 2021). Penelitian berikutnya yang dilakukan oleh (Widuri, 2020) mengenai pelatihan membaca Al-Quran untuk menurunkan tingkat cemas, dengan pelatihan ini kondisi individu menjadi lebih stabil sehingga berangsurangsur dapat menerima kondisi yang dialami. Terapi psikoreligius dilakukan seminggu 2 kali dan dilakukan setelah sholat Magrib.

\section{Pengaruh Terapi Psikoreligius Terhadap Kecemasan lansia}

Berdasarkan table 6 diatas bahwa dari 13 lansia yang mengalami cemas berat sebelum diberikan terapi psikoreligius sebanyak 10 orang $(33,4 \%)$ mengalami cemas sedang setelah diberikan terapi psikoreligius dan sebagian kecil 3 orang (10\%) masih mengalami cemas berat. Dari 14 lamsia yang mengalami cemas sedang sebelum dilakukan terapi psikoreligius didapatkan sebanyak 6 orang $(20 \%)$ mengalami cemas ringan, sebanyak 7 orang $(23,3 \%)$ mengalami cemas sedang dan 1 orang $(3,3 \%)$ mengalami cemas berat.

Hasil analisis dengan uji wilcoxon yang menggunakan program SPSS PC for Windows versi 20.0 didapatkan hasil bahwa nilai signifikansi $(p$ sign $=0,000)$ dimana hal ini berarti $p<0,05$ maka $\mathrm{H}_{1}$ diterima, artinya ada pengaruh dengan pemberian terapi psikoreligius terhadap kecemasan pada lansia.

Terapi psikoreligius jika dilihat dari sisi sains, terapi dzikir dan mendengarkan ceramah agama akan memunculkan suatu medan gelombang yang akan memengaruhi gelombang otak manusia. Menggunakan alat Electro Encephalo Graph (EEG), terlihat 
reaksi otak berupa perubahan gelombang otak dari frekuensi beta menjadi frekuensi alfa sehingga menyebabkan tubuh dalam keadaan relaksasi. Semua reaksi pada otak yang dipengaruhi oleh medan gelombang delta akan meningkatkan berbagai neurotransmitter, seperti serotonin dan dopamin yang pada akhirnya akan memberikan efek pada tubuh sehingga akan muncul ketentraman dan perasaan tenang pada hati.

Perasaan tenang yang ditimbulkan dari terapi dzikir diharapkan bisa mengurangi kecemasan yang dialami selama masa pandemi covid 19. Gejala-gejala cemas pada diri seseorang seringkali tidak disadari karena perjalanan awal tahapan cemas akan timbul secara lambat dan baru dirasakan apabila tahapan gejala sudah lanjut dan mengganggu fungsi kehidupannya sehari-hari baik di rumah ataupun pergaulan lingkungan sosialnya. Maka untuk mengendalikan diperlukan upaya mengubah persepsi pribadi mengenai sebuah keadaan untuk mengatasi keadaan tersebut yaitu sikap, keyakinan dan pikiran harus positif serta mengendalikan faktor-faktor penyebab lainnya agar kecemasan berkurang atau dapat dialihkan.

\section{F. PENUTUP}

Bahwa responden sebelum diberikan terapi psikoreligius didapatkan tingkat cemas ringan 3 orang (10\%), cemas sedang 11 orang (37\%) dan cemas berat sebanyak 16 0rang (53\%). Bahwa responden sesudah diberikan terapi psikoreligius didapatkan tingkat cemas ringan 8 orang (27\%), cemas sedang 18 orang $(60 \%)$ dan cemas berat sebanyak 4 Orang (13\%). Bahwa dari 13 lansia yang mengalami cemas berat sebelum diberikan terapi psikoreligius sebanyak 10 orang $(33,4 \%)$ mengalami cemas sedang setelah diberikan terapi psikoreligius dan sebagian kecil 3 orang (10\%) masih mengalami cemas berat. Bahwa dari 14 lamsia yang mengalami cemas sedang sebelum dilakukan terapi psikoreligius didapatkan sebanyak 6 orang $(20 \%)$ mengalami cemas ringan, sebanyak 7 orang $(23,3 \%)$ mengalami cemas sedang dan 1 orang $(3,3 \%)$ mengalami cemas berat. Bahwa dari 3 lansia yang mengalami cemas ringan sebelum dilakukan tindakan terapi psikoreligius didapatkan 2 orang $(6,7 \%)$ mengalami cemas ringan

\section{G. DAFTAR PUSTAKA}

Adriani, Wirjatmadi. 2012. Peranan Gizi dalam Siklus Kehidupan. Jakarta: Prenada Media Group.

Almatsier Sunita. 2010. Penuntun Diet Edisi Baru. Jakarta: Gramedia Pustaka Utama

Bensan, Ralph C. 2008. Buku Saku Obstetri \& Ginekologi. Jakarta: EGC.

Febry, Nurul, Ibnu. 2013. Ilmu Gizi untuk Praktisi Kesehatan. Yogyakarta: Graha Ilmu.

Hartono, Andry. 2006. Terapi Gizi dan Diet Rumah Sakit Edisi 2. Jakarta: EGC.

Indrayani, 2011. Buku Ajar Asuhan Kehamilan. Jakarta: Trans Info Media.

Maryuani Anik, 2010. Biologi Reproduksi dalam Kebidanan. Jakarta: Trans Info Media.

Nursalam. 2008. Konsep dan Penerapan Metodologi Penelitian Ilmu Keperawatan. Jakarta: Salemba Medika.

Proverawatai Atikah dan Asfuah Siti. 2010. Buku Ajar Gizi untuk Kebidanan. 
Yogyakarta: Nuha Medika.

Rudianto F. Budi. 2013. Menaklukan Hipertensi dan Diabetes. Yogyakarta: Sakkhasukma.

Soekidjo Notoatmodjo. 2010. Ilmu Perilaku Kesehatan. Jakarta: Rineka Cipta.

Soenanto Hardi. 2009. 100 Resep Sembuhkan Hipertensi, Asam Urat, dan Obesitas. Jakarta 